\title{
POTENTIALS FOR DEVELOPMENT OF RURAL TOURISM IN BAČKI PETROVAC MUNICIPALITY ${ }^{1}$
}

\author{
Radovan Pejanović2 ${ }^{2}$ Dunja Demirovic ${ }^{3}$, Jasmina Đorđevićc ${ }^{4}$, Gordana Radovic ${ }^{5}$
}

\begin{abstract}
Summary
The main goal of this paper is to prove the assumption that in the municipality of Backi Petrovac there is a predisposition for the development of rural tourism, taking into consideration the existing Spatial plan of the municipality, its conception and planning priorities. The analysis of internal and external preconditions for the development of tourism was conducted and also a field survey of registered rural households. Results of the analysis show that the external features do not represent a significant obstacle to the development of tourism, while on the other hand internal assumptions can be a limiting factor because of the extremely unfavourable demographic situation and the inadequate offer of rural households, which are mainly based on the services of accommodation. Proposals for the development of tourism through tourist spots have been given, noting which combination of existing tourist attractions is the best for the further development of every place except Maglic because this settlement has no predisposition for the development of rural tourism. In order to position tourism as an important economic activity and appropriate use of all available resources eight activities which are necessary to be conducted in the future have been proposed.
\end{abstract}

Key words: spatial planning, rural tourism, the municipality of Bački Petrovac

JEL: L83, O13, Q12

1 Paper is a part of research within the project no. III 46006 - Sustainable agriculture and rural development in the function of accomplishing strategic objectives of the Republic of Serbia in the Danube region, financed by the Ministry of Education, Science and Technological Development of the Republic of Serbia. Project period: 2011-2014.

2 Radovan Pejanović, Ph.D., Full Professor, Faculty of Agriculture, Trg Dositeja Obradovića no. 8, 21000 Novi Sad, Serbia, Phone: +381 63600 217, E-mail: pejanovic@polj.uns.ac.rs

3 Dunja Demirović, M.Sc., PhD student, Faculty of Sciences, Trg Dositeja Obradovića no. 3, 21000 Novi Sad, Serbia, Phone: +381 642686 290, E-mail: demirovic.dunja2@gmail.com

4 Jamina Đorđević, Ph.D., Full professor, Faculty of Sciences, Trg Dositeja Obradovića no. 3, 21000 Novi Sad, Serbia, Phone: +381 21485 2837, E-mail: jasmina.djordjevic@dgt.uns.ac.rs

5 Gordana Radović, M.Sc., PhD student, Faculty of Agriculture, Trg Dositeja Obradovića no. 8, 21000 Novi Sad, Serbia, Phone: +381 641378 643, E-mail: gordana.radovic09@gmail.com

EP 2014 (61) 2 (487-500) 


\section{Introduction}

In many countries spatial planning is used to strengthen regional economic development, the rational organization of place, achieving balance between developmental needs and demands of environmental protection and other goals and politics (Đorđević et al., 2008). Tourism has numerous economic and social functions and the ability to influence the development of other economic activities, so its spatial planning and deployment has become an integral part of overall development plans. Tourism and spatial planning are two interrelated processes and should be based on real social, economic, cultural and political conditions/circumstances in the region. Spatial planning is a tool for organizing tourism activities to facilitate the integration of this sector with other sectors and areas within a locality or region (Dede, Ayten, 2012).

In most countries, spatial planning is associated with urban areas, while rural areas are under-represented (Udovč, 2007). Spatial planning in rural areas must adapt to the specific situation and challenges in each area and respond by developing adequate visions, strategies and tasks that have the full support of local inhabitants, organisations and authorities as well as other important actors (Amdam, 2005). During the planning and development of rural areas it is necessary that the use of the space is clearly defined and that the effects and the implementation of the spatial plan are known. Only in this case the approved spatial plan can be implemented, and that through the implementation control actions in the planning area.

The possibility of development of rural tourism in the Municipality of Bački Petrovac according to the Spatial plan of the municipality has been analyzed in this paper. Municipality of Bački Petrovac is the smallest municipality in Vojvodina and it belongs to South Bačka District, consisting of four villages: Bački Petrovac, as the centre of the municipality, Kulpin, Maglić and Gložan. The municipality has a very favourable geo-strategic position as it is located only $25 \mathrm{~km}$ from Novi Sad, which is a functional urban area of international significance. The area of municipality lies on the banks of the Danube River in the village Gložan and it is intersected by a network of canals of irrigation system Danube - Tisa Danube (DTD). Through the village Gložan passes Danube bike path Eurovelo 6. In this area there are also small game hunting grounds, and DTD canal and the Danube River are rich in fish. According to the last census (2011), in the Municipality of Bački Petrovac live 13.302 inhabitants and the municipality is multi-ethnic and multi-cultural environment, and majority of population is of Slovakian (66.42\%) and Serbian (25.74\%) nationality. Municipality of Bački Petrovac is characterized by intensive agricultural production and investment in the development of agro-industry. Second place is held by industry, and it is followed by manufacturing, public work/activity, services and other activities. Crafts evolved along with the economy, and today also intensively the rural tourism.

\section{Rural tourism in the existing planned documents of the Republic of Serbia}

Spatial Plan of the Republic of Serbia- the period from the year 2010 to the year 2020 (2010) aims to regulate the use, development and protection of the country's territory. In 
terms of economic development of Serbia, the advantage will be in addition to agriculture and energy resources given to tourism since those are activities whose available resources, market conditions and technical advances allow faster development. The SWOT analysis of spatial development of the Republic of Serbia as one of the advantages pointed out the existence of a number of areas with potential for development of rural tourism. One of the basic strategic priorities of the Republic of Serbia prominent in the national spatial plan is the restoration and development of rural areas and villages in a sustainable and socially rational way. To achieve this, emphasis will be placed on the development of agriculture according to the model of multifunctional agriculture and introduction of additional activities (handicrafts, various forms of rural tourism, hunting, fishing, etc.). In order to further and better develop the agriculture in the whole country certain economic and financial measures have been provided that involve the development of compatible non-agricultural activities such as agro-tourism and other forms of tourism, crafts, recreation, small industrial plants, the introduction of special loan programs and easier access to loans for women who live in rural areas and are engaged in agricultural production and rural development, as well as other forms of economic activity in the country, including rural tourism and healthy/eco food production. Rural tourism is recognized as one of the key tools for developing regions with low agro-ecological potential, underdeveloped agricultural structure and preserved natural areas.

In The Regional Spatial Plan of AP Vojvodina until the year of 2020 (2011) it was pointed out that the involvement of tourism in economy and employment is low, which shows that its potentials have not been fully exploited. The form of tourism which prevails is the city tourism because the urban centres have the highest tourist traffic. Although, according to the Tourism Strategy of the Republic of Serbia, rural tourism is one of the key aspects of tourism in Vojvodina, in the Spatial plan it was marked as a tourist product of exceptional potential, but not enough furnished and unrecognized. Among the basic principles of spatial development of AP Vojvodina the guidelines for the preservation, enhancement, protection and sustainable use of natural resources and cultural heritage have been raised, which should be the basis of tourist, but also economic development, while within the goals of the regional spatial development prominent role has the strengthening of the position of the village, and it is believed that villages which focus their development on tourism, agriculture and industry would become a significant factor in the development. One of the forms of tourism that is related to the rural area is rural tourism which, according to the spatial plan, is carried out in two forms: on farms and as tourism in rural areas, but villages that have tourist function have not yet been codified as rural tourist spots. As for the municipality of Backi Petrovac the analysis of demographic indicators revealed that it belongs to a demographic endangered area, which can have a very negative effect on its further development. The segment of tourism of Bački Petrovac municipality has not been specifically addressed in the Regional Spatial Plan of AP Vojvodina, but its particular value has been recognized for the spatial development of AP Vojvodina. From tourist attractions on several places have been highlighted the importance of the castle in Kulpin. Among other tourist attractions of Bački Petrovac municipality the Slovaks have been mentioned as 
a nation that has preserved its tradition which provides an opportunity to realize the vision of Vojvodina as a "multicultural and humane".

Certainly the most detailed document when it comes to tourism development in the municipality of Bački Petrovac is The Spatial Plan of the municipality Bački Petrovac (2007), in which as the main goal of the creation of Plan in terms of tourism is set valorisation of all natural and anthropogenic values in the municipality on the basis of which forms of tourism that could be developed in order to increase tourist traffic, and therefore revenue from tourism would be determined. In the municipality it is possible to develop different forms of tourism (cultural manifestation, hunting, fishing, sports and recreation, cycling and rural tourism) due to favourable natural predisposition. The biggest limitation for the development of tourism is the lack of clearly defined tourism product, unsatisfactory material basis of receptive tourism in terms of the number of facilities, but also the quality of services, and lack of a strategy for tourism development of areas, which would include a clear model of the development of this activity. Based on the analysis of natural and created values the entire municipality was divided into two territorial units, or zones: The River bank zone of the Danube River, forests, tourism, recreation and agricultural production and The Zone of intensive agricultural production. Among the important objectives whose fulfilment will contribute to the development of tourism raises the further protection of natural and cultural resources in order to develop tourism which will on the one hand threaten natural values, and on the other hand will contribute to the preservation of the material heritage of national culture as a prerequisite for the preservation of national identity. Municipal spatial plan envisages that tourism would be one of the leading economic activities in the future.

\section{Natural, cultural and historical values of importance for the development of rural tourism in Municipality of Bački Petrovac}

In the municipality there are natural sites that may be of importance for the development of tourism, and some of them are in the process of protection as they have great value. In the process of protection is the park around the castle Dunđerski in Kulpin in which there are rare and protected plant species. The remains of Gložan Rit, which consists of depressions under the reeds which serve as nesting for wildfowl, natural rarities are also predicted for protection. The $1^{\text {st }}$ degree of protection mode is respected in this site. The municipality has a rich fauna so it is possible to develop hunting and fishing tourism.

Among the immovable cultural property whose value has been recognized and featured in the Spatial Plan of the municipality (2007) for the development of tourism stand out facilities that are monuments of folk architecture and construction. The architectural development of the rural houses can be traced back to the late eighteenth to the early nineteenth century, and the oldest type of house is "Homeland House" (Bački Petrovac), which is the most important work of the old architecture of Vojvodina in the $18^{\text {th }}$ century. It was built in 1864 and it represents the only preserved old hemp-spinning mill in the territory of Vojvodina.

The next important piece of architectural heritage, the Slovak Evangelical Church with the parish centre in Bački Petrovac was built in 1783. Parish House of the Evangelical church 
represents the most characteristic features of the classicist style that dominated in the first half of the $19^{\text {th }}$ century and at the same time it is one of the very few buildings of this period on the territory of Vojvodina, which has been preserved in its original appearance.

Based on the analysis of the Spatial Plan of the municipality (2007), the authors recognize that some of the values of importance for the development of rural tourism were omitted or only mentioned adequate valorisation. In the Regional Plan it was only mentioned the existence of association AHOJ, and it is of great importance for rural tourism since it is a unique meeting centre of craftsmen, farmers and artists in order to preserve and encourage the development of traditional crafts, preservation of traditional cuisine and healthy environment.

In addition, in the Spatial Plan of the municipality (2007) points out that the two castles (Dunđerski), park and fence surrounding the palace in Kulpin are placed under the state protection. It is mentioned that in the castle today there is an agricultural museum; however, what is not stated is that the museum is the only specialized museum institution in the country for research and study of the agrarian sector, established in 1993 (Kišgeci 2010).

Picture 1. Castle Dunđerski in Kulpin Picture 2. Event "Wedding then and now"
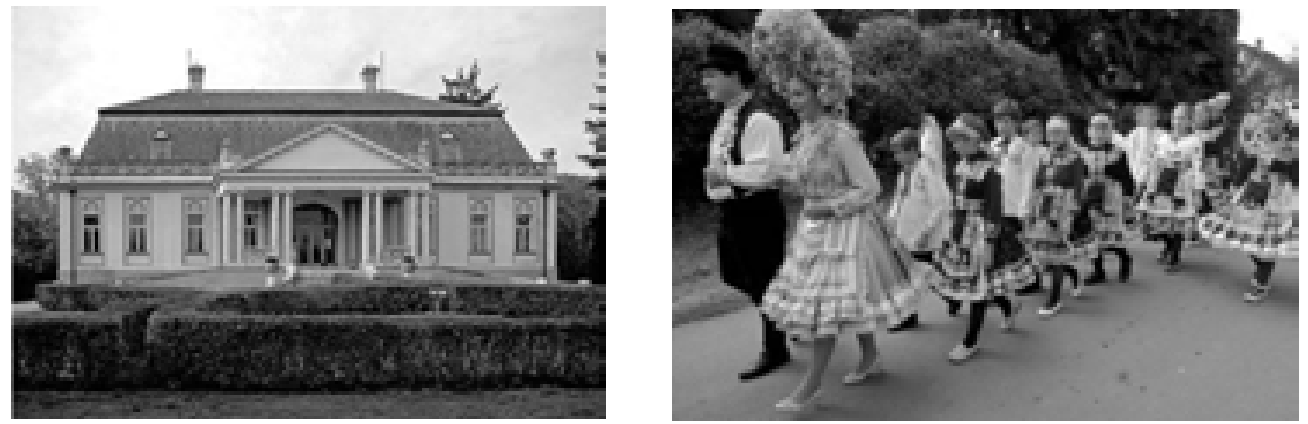

Source: Tourist Organization of Bački Petrovac.

For the development of current and potential tourism products of the municipality from events the importance of only one event was highlighted, although there are others that might be attractive to tourists. In the Regional Plan of the Municipality traditional event of Slovaks has been mentioned, Slovak National Festival (the first was held in 1919). At this event shows the folk and contemporary art of Slovaks in Serbia and the region are presented. Among the other events that might be found in the offer of rural tourism are the events "Dance, Dance" ("Tancuj, tancuj"), (since 1970.), in which the costumes, dancing and singing groups are presented, "Wedding then and now", an international event that is held in Kulpin, in the castle Dunđerski, in which the wedding customs, antique wedding dress are presented and local dishes are served.

Gastronomy, although it has considerable potential for tourism development, is omitted from the Spatial Plan of the municipality. Slovak dishes which, prepared in a traditional way, can be an attractive tourism product include: Krumple na Tapsi (potato casserole), 
Kapustnica (traditional soup), Bryndzove halusky (potato dumplings in melted cream), Retes (a dish of sour dough that is stretched into the crust and filled with cheese, potatoes, pumpkin, cherry or grits), "Petrovac cakes" which are specific in that they are high, large and full of ornaments.

A special culinary product to which to the event is dedicated (Festival of pork sausage) is a "Petrovac Sausage" ("Petrovska klobasa"), which is the first food product from Serbia who won the right to protect its geographical origin. It was first officially mentioned in the great exhibition of agricultural products in 1873 in Vienna (Elaborat, 1992).

Analysing the natural, cultural and historical value, it is evident that rural tourism has a good basis for making a quality tourism product that could in correlation with hunting, sports and recreation and event tourism and with the high-quality, sustainable strategy and modern marketing approach significantly contribute to the socio-economic recovery and sustainable development of the entire municipality.

\section{Valorisation of the basic assumptions of importance for the development of rural tourism in the Municipality of Bački Petrovac}

According to numerous studies (Ćatović, Mešković, 2011; Vukoja, 2011; Klarić, Gatti, 2006) the basic assumptions for the development of rural tourism are assumptions of the environment (external assumptions - clean air and water, preserved nature and natural heritage, cultural heritage, good traffic and telephone connection, commitment and affection of the community and institutions towards the tourist activities) and the assumptions in the household (internal assumptions - the possession of the estate, commercial and residential property, possession of livestock, the ability of rural production presentations, attractiveness of location and residential building, resolved communal infrastructure of the household, as well as the number, age and the tendency of members of rural households to provide tourist services).

Conditions of major infrastructure in the municipality of Bački Petrovac could be assessed as satisfactory. All paved roads in the municipality are $28 \mathrm{~km}$ long and belong to the third category. According to the level of modernization of roads, this municipality, of the 45 municipalities in Vojvodina, takes place 7. Good traffic communication, accessibility to a broader level and closeness to Novi Sad as one of the most important emissive tourist centres can enhance the attractiveness and visit to the municipality of Bački Petrovac.

Significant environmental and largely unsolved problem in all of the Republic of Serbia is the disposal of waste. With the organized collecting of waste only about $60 \%$ of the urban population is covered, while in rural areas there is almost no organized waste collection (Zelenović Vasiljević, 2011). A significant source of pollution in the municipality of Bački Petrovac represents municipal solid waste landfill located near the village and even in the village itself. None of the landfill has the necessary documents, the necessary protective measures are not performed, and only the landfill in Gložan has a protective strip. Inadequate waste management can have a negative impact on the image of tourist destinations, especially those who want to develop rural tourism. 
The state of public service facilities which are important for the stay of tourists is good, a little denser network structures are characteristic of the health and culture. The capacity of health facilities (clinics, health centres) is appropriate, but in rural areas it is necessary to provide better equipment. In all areas, there are pharmacies and veterinary stations. The capacity of cultural institutions (cultural centres, museums, galleries and exhibition spaces) are sufficient, but it is necessary to introduce new and more modern contents. In the municipality of Bački Petrovac several outdoor swimming pools have been built. Among the special attractions in the municipality there is the aqua park "Petroland" opened in April of 2012, which represents the largest so far built tourist and entertainment attraction in Serbia and the most modern aqua park in the Balkans.

The attitude of the local population about the importance of tourism on the development of an area is very important, especially in those rural areas with preserved ecosystem. According to earlier conducted studies (Čomić, 2010) on a sample of 100 citizens in Bački Petrovac, customs and events may be the most interesting for tourists, and when it comes to understanding the potential benefits that rural tourism can bring to the community what singles out is the increase of employment of local population, development of manufacturing and service industries, rich cultural life and creating opportunities for young people to stay in rural areas. This research conducted shows that there is a positive attitude of the local community towards the development of rural tourism in the municipality and that they recognize only the positive effects that this type of tourism can bring, so it is necessary to further inform and educate the local community to take active participation in providing services to tourists.

According to the Tourism Organization of Bački Petrovac there are registered 16 people that provide accommodation services (capacity of 85 beds in 45 rooms), and among them dominates accommodation in apartments and private homes and providing a bed and breakfast service. The existing accommodation capacities are characterized by insufficient number and equipment. Favourable situation is with catering facilities and restaurants which are present in every place of the municipality (about 50), and some facilities have sports and leisure facilities. It is essential to raise the level of service in the existing restaurants and to serve mainly local food and drink as they can be an attractive tourist product. Analysing the current external conditions for the development of rural tourism in the municipality, it can be concluded that they do not represent a significant obstacle to the development of this type of tourism, and some of them (already built all kinds of infrastructure, existing public service, positive attitude of the local community towards the development of tourism) can be incentive for further development.

The problems that the rural area is facing have become almost universal at level of the whole world. Demographers and economists point out the alarming demographic trends that have a negative impact on many industries, including tourism. Numerous studies (Pejanović, 2010; Milovanović et al., 2010; Pejanović, 2013) point out that the rural areas are faced with reduced fertility and birth, increased inequalities between age groups, the aging of the population, increased external migration. 
According to the census from 2002 in four villages of the municipality of Bački Petrovac lived 14,681 people (according to the census of 2011. 13,302 inhabitants) (Table 1.), while in the centre of the municipality lived $45.8 \%$ of the population (in $2011.45 .58 \%$ ). Analysis of the movement of total number of population of the municipality Bački Petrovac, for the period from 1948 to 2002, showed a trend of increasing the total number of population, at an average annual rate of $0.11 \%$, however, population policy has a trend of continuing decline in population since the Census from 1981.

Table 1. Population trends from 1948. to 2002.

\begin{tabular}{|l|r|r|r|r|r|r|r|}
\hline \multirow{2}{*}{ Settlement } & \multicolumn{7}{|c|}{ Census year } \\
\cline { 2 - 8 } & $\mathbf{1 9 4 8}$ & $\mathbf{1 9 5 3}$ & $\mathbf{1 9 6 1}$ & $\mathbf{1 9 7 1}$ & $\mathbf{1 9 8 1}$ & \multicolumn{1}{c|}{$\mathbf{1 9 9 1}$} & \multicolumn{1}{c|}{$\mathbf{1 0 0 2}$} \\
\hline B. Petrovac & 7,452 & 7,503 & 8,104 & 7,822 & 7,729 & 7,229 & 6,727 \\
\hline Gložan & 2,776 & 2,754 & 2,839 & 2,682 & 2,569 & 2,487 & 2,283 \\
\hline Kulpin & 3,578 & 3,728 & 3,742 & 3,312 & 3,226 & 3,207 & 2,976 \\
\hline Maglić & 8 & 1,157 & 2,180 & 2,226 & 2,571 & 2,733 & 2,695 \\
\hline Municipality & 13,814 & 15,142 & 16,865 & 16,042 & 16,095 & 15,656 & 14,681 \\
\hline
\end{tabular}

Source: The Spatial Plan of the municipality of Bački Petrovac (2007).

Analysis of the population structure according to large age groups indicates unfavourable age structure of the population with high aging index of 1.0, which in settlements ranges from 0.9 (Kulpin, Maglić) to 1.1 Gložan. If this index is compared with data from the National Rural Development Programme 2011-2013, and the Plan of Rural Development Strategy 20092013, it can be concluded that it is lower than the rate of population aging in rural areas all over Serbia which amounts $1.08 \%$. Disturbing information in the municipality is that older middle aged and old people constitute $51.7 \%$ of the total population.

Observing the settlements, the highest percentage of highly educated people is in Bački Petrovac, in Maglić is the highest percentage of completed secondary education, and in Kulpin with a degree in elementary education, which compared to prior periods indicates significant improvement of the educational structure of the population in the municipality.

Based on the mentioned data, the general demographic situation in the municipality of Bački Petrovac is unfavourable. It is necessary to increase the exploitation of rural areas in nonagrarian purposes, in order to increase income and improve the living conditions of the existing population, and to make the environment more attractive to attract new businesses and immigration of population from other parts.

In order to determine the internal characteristics of households that are engaged in tourism survey has been conducted during January 2014. by personal visit to randomly selected households. Six households, out of ten, were interviewed to determine whether the current offer matches the needs of the tourism market. All households are in Bački Petrovac. The questionnaire consisted of two parts and five questions, two of which were open-ended, where the respondents wrote responses, while other questions had offered answers.

Asked how many family members were involved in tourism, only in two households all family members were involved in rural tourism. With regard to the demographic characteristics of 
household members engaged in rural tourism it is observed that women predominate $(80 \%$ of respondents), that they completed secondary education, while the average age of people involved in tourism is 44 years.

The next question related to the characteristics of the households and respondents answered "yes" or "no." All the surveyed households have arranged driveway and parking area, but few have a clear or almost no set signs for tourists that it is a facility which provides accommodation. Also, all facilities have electricity and phone number (Mobile or Fixed), while e-mail have only two households. Of the total number of households, only one household has a shared bathroom, i.e. guest bathroom, which must be shared with the owner. None of the households has its own agricultural production, and only one household has domestic animals and ancillary facilities in the yard. When it comes to services provided to tourists, the average household has three beds, while breakfast is the only the food service, and it is practiced in three households. Buying food and various products such as Petrovac Sausage (pork sausage) and winter stores is available in only two households. None of the households provides the opportunity for tourists to actively or passively participate in the preparation of food with the hosts, as well as the opportunity to participate in the affairs of the host. Also, no household has organized workshops, and only one household has all conditions for sports and recreational activities. One household organizes excursions for tourists in the village and its surroundings, while others point out that they can always make recommendations to tourists what they should see.

When asked which the structure of visitors is the product intended to, all households responded that it fits all structures (students, youth, families, and the elderly), and that there is no special customization of products and services, depending on the structure of guests.

Analysing the responses received, it can be observed that the tendency of family members to provide tourist services is at a low level (e.g. in a household of five members, only one is involved in tourism), and it is necessary to encourage other members to be actively involved in the providing the services. Age and educational structure of persons engaged in tourism is somewhat satisfying, but it can certainly be improved by including other family members (a young and college-educated people). Lack of computers in households, the lack of e-mails and the presence on social networks reduces the possibility of households to have adequate marketing and attract more tourists. The biggest drawback of households represents a very modest tourist product consisting mainly of providing accommodation, i.e. bed and breakfast with no additional activities for visitors. Considering the fact that households do not have adequate resources to organize additional activities, it is necessary to encourage rural households to engage in tourism because it would enrich the final product (e.g. the ability to participate in agricultural work).

\section{Discussion}

In order to position tourism as a major economic activity and appropriate use of all available resources, it is necessary to fulfil the following:

EP 2014 (61) 2 (487-500) 
1. Record the existing tourism resources and make their valorisation - it is necessary to establish a tourism database and perform a valuation of resources in accordance with the requirements of tourism demand and sustainable development of tourism;

2. Establish a tourism offer - It is desirable to create an offer that will combine different types of tourism and thus emphasize the priority forms and scale of tourism activities, and in this way achieve diversity of the offer. It is necessary to avoid forcing the development of tourism in the entire municipality, but focus on those sites that are predisposed.

3. Perform segmentation of tourists - Holders of tourism offer in the Municipality of Bački Petrovac need to perform segmentation of tourists based on various criteria, because it is the only way to achieve a better market position against competitors.

4. Educate all participants in the tourism industry - it is necessary to educate professionals and the population as it is the only way to ensure sustainable tourism development.

5. Quantitative and qualitative improvement of accommodation capacities - to encourage local residents that they should by complying with the possibilities reorganize part of their household for the needs of receptive facilities or to build new ones. Motivation for this activity, the municipal government can achieve through soft loans or grants.

6. Improving the condition of public utilities - for tourism, it is necessary to provide at least an optimal level of equipment of infrastructure and superstructure. Adequate municipal system would allow a better connection between tourist facilities.

7. Formulating marketing strategy -Advertising material should be well designed and content should be presented in a professional manner and adapted to a particular type of tourists._Offer of the municipality should be presented on the sites of organizations at the regional and national level, in accordance with the financial capabilities of the domestic and international tourism fairs.

8. Formulating a strategy for tourism at the local level - strategy for tourism development in the municipality of Bački Petrovac should include all the mentioned points, and in addition it is necessary to define what are the individual forms of tourism that can develop in certain part of the municipality, to determine who are the subjects that will take care of the implementation of tourism (public enterprises, the private sector, tourism organizations, municipal bodies, etc.), and what are their powers, and to establish a public (municipal)-private partnership for better performance in the market.

Analysing existing tourism values in the municipality, the following spatial organization of tourism through tourist spots is proposed:

- Traditional architecture - on the territory of the municipality, especially in Bački Petrovac and Gložan a large number of authentic Slovakian house of charge with the original furniture have been preserved. It is necessary to maintain these facilities in order 
to prevent their devastation because it would lead to losing a significant part of the history of the region and an important tourism potential;

- Heritage area - Kulpin can be marked as heritage area because it possesses only agricultural museum in the country and as such can be very attractive and recognizable destinations.

- Active or passive participation in community life - in Bački Petrovac there the highest number of facilities where tourists can actively or passively participate in community life (association “AHOJ”, the gallery "Urbanček”, women's association). In Gložan, tourists can make themselves a souvenir of maize.

- Gastronomy - A special culinary product that should be promoted is the "Petrovac Sausage". Traditional dishes should prevail in the offer of private farms of rural farms and restaurants, and it is necessary to devise a better promotion of Gložan that is already among the tourists (small number) identified by the production of healthy food. Kulpin is becoming recognized for its production of wine;

- Events - Their importance lies in the fact that they preserve the tradition and activate almost the entire local community. Among the events that are recognized as a potential product in rural tourism as "Slovak National Festival" (Bački Petrovac), "Dance, Dance" (Gložan) and "Wedding then and now" (Kulpin);

- Recreation - current existence of sports and recreation complex "Oasis MB Gložan" and after the completion of project ethno-park "Danube dream" south of Glozan, on the Danube, this place could become a recognized destination for sports and recreational tourism.

\section{Conclusion}

Analysing all natural and anthropogenic values in the municipality of Bački Petrovac the assumption that there is a predisposition for the development of different forms of tourism, including rural tourism has been confirmed. Analysis of existing external preconditions for tourism development shows that they are not significant obstacles to the development of tourism, and even provide an adequate basis. However, in order to meet the basic needs of tourists, it is necessary to maintain existing external assumptions regularly, if needed to renovate or replace with the addition of new contents (cultural institutions and sports facilities). On the other hand, internal assumptions may represent a limiting factor for the development of rural tourism due to unfavourable demographic situation which together with the current trend of migration can be a factor of slowing down the entire rural development.

Existing supply of rural households is unsatisfactory because it is based on the providing the accommodation and breakfast with no additional activities that tourists can practice, that can cause dissatisfaction of tourists and their weak loyalty. There is currently no agricultural household engaged in tourism, so it is necessary to show how agriculture and tourism are related and which may have those who engage in this area. This would enrich the existing 
tourist offer; it would enable additional employment of family members, and would achieve the multifunctional agriculture development. Positive attitude of local people towards tourism development should be used in terms of them being stimulated to work in rural tourism. While on one hand the demographic situation is unfavourable, on the other hand, it is one of the most significant development potential because it has a quality workforce.

In the future, in order to have better position of tourism, it is necessary to do an accurate tourist data base and perform valorisation of all values. The creation of tourist offer should be based on these activities which would emphasize the priority forms and scope of tourism activities. Working on the development strategy of tourism in the municipality arises as a priority, since the existing spatial plan did not provide clear directions and concepts of tourism development, and some of the tourist attractions were just mentioned or completely omitted.

It is undisputed that the Municipality of Bački Petrovac has quality predisposition for the development of different forms of tourism, but without a clear vision of sustainable development and cooperation with the local population, tourism will not be among the holders of economic development.

\section{References}

1. Amdam, J. (2005): Spatial planning in rural areas, Collection of Papers - AESOP 2005 Congress, Vienna University of Technology, Austria, available on: www.hivolda.no/ neted/upload/attachment/site/group1/notat9-05.pdf

2. Ćatović, A., Mešković, M. (2011): Ruralni turizam na području Tuzlanskog kantona, Zbornik radova sa konferencije - Turizam u funkciji lokalnog razvoja, Fojnica, BiH, br. 4, str. 121-137.

3. Čomić, M. (2010): Seoski turizam u opštini Bački Petrovac, diplomski rad, Prirodnomatematički fakultet, Univerzitet u Novom Sadu, Novi Sad, Srbija.

4. Dede, O. M., Ayten, A. M. (2012): The role of spatial planning for sustainable tourism development: A theoretical model for Turkey, Tourism, vol. 60, no. 4, pp. 431 - 445, Institute for tourism, Vrhovec, Croatia.

5. Đorđević, D., Dabović, T., Živak, N. (2008): Osvrt na prostorno planiranje na početku 21. veka, Glasnik Geografskog društva Republike Srpske, br. 12, str. 37-87, Geografsko društvo Republike Srpske, Banja Luka, Republika Srpska.

6. Elaborat o zaštiti geografskog porekla Petrovačke kobasice, Zavod za intelektualnu svojinu, Beograd, Srbija, 1992.

7. Kišgeci, J. (2010): Poljoprivredni muzej - od ideje do ostvarenja i natrag, Iz istorije poljoprivrede, sveska 1, str. 7-15, Udruženje za muzejsku agrarnu baštinu, Kulpin, Srbija.

8. Klarić, Z., Gatti, P. (2006): Ekoturizam, u: Hrvatski turizam: plavo, bijelo, zeleno (ur. 
Sandra Čorak, Vesna Mikačić), str. 149-164, Institut za turizam, Zagreb, Hrvatska.

9. Milovanović, M., Radojević, V., Škatarić, G. (2010): Depopulacija kao faktor ruralnog i regionalnog ravoja u Crnoj Gori, Škola biznisa, br. 4/2010, str. 32-40, Visoka poslovna škola strukovnih studija, Novi Sad, Srbija.

10. Nacionalni program ruralnog razvoja Srbije 2011-2013, Ministarstvo poljoprivrede, šumarstva i vodoprivrede, Srbija, 2011.

11. Pejanović, R. (2010): Demografski problemi kao ograničavajući faktori ruralnog razvoja AP Vojvodine, Glasnik Antropološkog društva Srbije, vol. 45, str. 65-75, Antropološko društvo Srbije, Novi Sad, Srbija.

12. Pejanović, R. (2013): Ogledi iz agrarne i ruralne ekonomije. Univerzitet u Novom Sadu, Poljoprivredni fakultet, Departman za ekonomiku poljoprivrede i sociologiju sela, Novi Sad, Srbija.

13. Plan strategije ruralnog razvoja 2009-2013, Ministarstvo poljoprivrede, šumarstva i vodoprivrede, Srbija, 2009.

14. Popis stanovništva, domaćinstava i stanova u Republici Srbiji 2011. (prvi rezultati), bilten 450, Republički zavod za statistiku, Beograd, Srbija.

15.Prostorni plan opštine Bački Petrovac, JP Zavod za urbanizam Vojvodine, Novi Sad, Republika Srbija, 2007.

16. Prostorni plan Republike Srbije 2010 - 2014 - 2021, Ministarstvo životne sredine i prostornog planiranja, Republička agencija za prostorno planiranje, Beograd, 2010.

17.Regionalni prostorni plan Autonomne pokrajine Vojvodine do 2020. godine, JP Zavod za urbanizam Vojvodine, Novi Sad, 2012.

18. Udovč, A. (2007): Rural Space Planning as a Tool for Natural Resource Management in Slovenia, The Romanian Economic Journal, No. 25 bis 3, pp. 347-364, Bucharest Academy of Economic Studies, Bucharest, Romania.

19. Vukoja, B. (2011): Razvitak ruralnog turizma u BIH sa naglaskom na Hercegovačku regiju, Zbornik radova sa konferencije - Turizam u funkciji lokalnog razvoja, Fojnica, BiH, br. 4, str. 213-229.

20.Zakon o planiranju i izgradnji, Službeni glasnik RS, br. 72/2009, 81/2009- ispravka, $64 / 2010$ US i 24/2011.

21.Zelenović Vasiljević, T. (2011): Primena GIS-a, analitičkog hijerarhijskog procesa ifazi logike pri izboru lokacija regionalnih deponija i transfer stanica, doktorska disertacija, Fakultet tehničkih nauka, Univerzitet u Novom Sadu, Novi Sad, Srbija. 


\title{
POTENCIJALI RAZVOJA RURALNOG TURIZMA U OPŠTINI BAČKI PETROVAC ${ }^{6}$
}

\author{
Radovan Pejanović ${ }^{7}$, Dunja Demirovićc ${ }^{8}$, Jasmina Đorđevic ${ }^{9}$, Gordana Radović1
}

\begin{abstract}
Rezime
Osnovni cilj ovog rada je da dokaže pretpostavku da na području opštine Bački Petrovac postoji predispozicija za razvoj ruralnog turizma uzimajući u obzir postojeći Prostorni plan opštine, njegovu koncepciju i planske prioritete. Izvršena je analiza internih i eksternih pretpostavki za razvoj turizma i sprovedeno je terensko anketno istraživanje registrovanih seoskih domaćinstava. Rezultati analize pokazuju da eksterne karakteristikene predstavljaju značajniju prepreku za razvoj turizma, dok s druge strane interne pretpostavke mogu biti ograničavajući faktor zbog izrazito nepovoljne demografske situacije i neadekvatne ponude seoskih gazdinstava koja se u najvećoj meri bazira na pružanju usluga smeštaja. Dati su predlozi za prostornu organizaciju turizma kroz turističke tačk, ističući koja je kombinacija postojećih turističkih vrednosti najbolja za dalji razvoj svakog mesta osim Maglića jer ovo naselje nema predispozicije za razvoj ruralnog turizama. U cilju pozicioniranja turizma kao značajne privredne delatnosti $i$ adekvatnog korišćenja svih raspoloživih resursa predloženo je osam aktivnosti koje je neophodno sprovesti u narednom periodu.
\end{abstract}

Ključne reči: prostorno planiranje, ruralni turizam, opština Bački Petrovac.

6 Rad je deo Republičkog projekta broj III 46006, finansiran od strane Ministarstva prosvete, nauke i tehnološkog razvoja.

7 Dr Radovan Pejanović, redovan profesor, Poljoprivredni fakultet, Trg Dositeja Obradovića 8, 21000 Novi Sad, Srbija, Telefon: +381 63600 217, E-mail: pejanovic@polj.uns.ac.rs

8 M.Sc. Dunja Demirović, student doktorant, Prirodno-matematički fakultet, Trg Dositeja Obradovića 3, 21000 Novi Sad, Srbija, telefon: +381 642686 290, E-mail: demirovic.dunja2@gmail.com

9 Dr Jamina Đorđević, redovan professor, Prirodno-matematički fakultet, Trg Dositeja Obradovića 3, 21000 Novi Sad, Srbija, Telefon: +381 21485 2837, E-mail: jasmina.djordjevic@dgt.uns.ac.rs

10 Mr Gordana Radović, student doktorant, Poljoprivredni fakultet, Trg Dositeja Obradovića 8, 21000 Novi Sad, Srbija, Telefon: +381 641378 643, E-mail: gordana.radovic09@gmail.com

EP 2014 (61) 2 (487-500) 